\title{
Quality of clinical guidelines in pediatric headache
}

\author{
Pasquale Parisi \\ From 70th Congress of the Italian Society of Pediatrics, Joint National Meeting SIP, SICUPP, SITIP \\ Palermo, Italy. 11-14 June 2014
}

\begin{abstract}
Background
Headache is a very common complaint in children, and can have a profound impact on school performance [1], being the major cause of absence from school [2], and interfering with other daily activities [3]. The studies based on parental reports may be an unreliable source of information on the frequency of headache in young children; in fact, it has been suggested that almost 36\% of the parents of children with headache are unaware of the headache [4]. In any case, the increased incidence over the last 30 years probably reflects the significant changes in children's lifestyles.

Given the elevated prevalence and the associated high degree of disability, it is not surprising that headache represents an important public health issue with considerable costs for the National Health Care System (NHCS), although, as children are not directly involved in the productivity process, it is not so easy to quantify the enormous, both, direct and indirect NHCS costs in this population [5].
\end{abstract}

\section{Methods}

To assess the appropriateness and uniformity of application of the available pediatric clinical guidelines (CGs) for the diagnosis and treatment of headache in children, It has been conducted a systematic literature search using the following terms: headache, cephalalgia, guidelines and children (MESH or text words). Six CGs containing informations on the diagnosis and management of headache with specific recommendations for children were selected [6-11]. Eleven neuropediatric centers evaluated,

Correspondence: pasquale.parisi@uniroma1.it

NESMOS Department, Chair of Paediatrics, Pediatric Headache Centre, Paediatric Sleep Centre \& Child Neurology, Faculty of Medicine \&

Psychology, "Sapienza University", Sant'Andrea Hospital, Via di Grottarossa, 1035-1039, Rome, Italy 
of the Quality Standards Subcommittee of the American Academy of Neurology and the Practice Committee of the Child Neurology Society. Neurology 2002, 59:490-498

7. Ad Hoc Committee: Linee guida sulla cefaea giovanile. 2003 [http://www. sinpia.eu/atom/allegato/153.pdf].

8. Lewis D, Ashwal S, Hershey A, Hirtz D, Yonker M, Silberstein S: American Academy of Neurology Quality Standards Subcommittee; Practice Committee of the Child Neurology Society. Practice parameter: pharmacological treatment of migraine headache in children and adolescents: report of the American Academy of Neurology Quality Standards Subcommittee and the Practice Committee of the Child Neurology Society. Neurology 2004, 63:2215-2224.

9. Géraud G, Lantéri-Minet M, Lucas C, Valade D: French Society for the Study of Migraine Headache (SFEMC). French guidelines for the diagnosis and management of migraine in adults and children. Clin Ther 2004, 26:1305-1318.

10. Bendtsen L, Birk S, Kasch H, Aegidius K, Sørensen PS, Thomsen LL, Poulsen L, Rasmussen MJ, Kruuse C, Jensen R: Reference programme: diagnosis and treatment of headache disorders and facial pain. Danish Headache Society, 2nd edition. J Headache Pain 2012, 13(Suppl 1):S1-S29.

11. Guideline Development Group: Headaches: Diagnosis and management of headaches in young people and adults: NICE guidance 2012. NICE guideline 2012 [http://www.nice.org.uk/Guidance/cg150].

doi:10.1186/1824-7288-40-S1-A86

Cite this article as: Parisi: Quality of clinical guidelines in pediatric headache. Italian Journal of Pediatrics 2014 40(Suppl 1):A86.

\section{Submit your next manuscript to BioMed Central and take full advantage of:}

- Convenient online submission

- Thorough peer review

- No space constraints or color figure charges

- Immediate publication on acceptance

- Inclusion in PubMed, CAS, Scopus and Google Scholar

- Research which is freely available for redistribution

Submit your manuscript at www.biomedcentral.com/submit 